\title{
Digital ambidexterity in the public sector: empirical evidence of a bias in balancing practices
}

\author{
Johan Magnusson
}

\author{
Swedish Center for Digital Innovation, University of Gothenburg, Gothenburg, \\ Sweden and Kristiania University College, Oslo, Norway \\ Tero Päivärinta \\ M3S, Oulu University, Oulu, Finland, and \\ Dina Koutsikouri \\ Swedish Center for Digital Innovation, University of Gothenburg, Gothenburg, Sweden
}

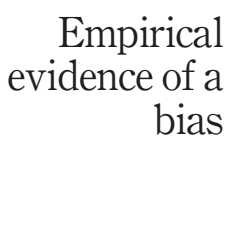

bias

\begin{abstract}
Purpose - The purpose of this study is to explore and theorize on balancing practices (BP) for digital ambidexterity in the public sector.

Design/methodology/approach - The research is designed as an interpretative case study of a large Swedish authority, involving data collection in the form of interviews and internal documents. The method of analysis involves both theorizing on the findings from a previous framework for digital innovation and deriving design implications for ambidextrous governance.

Findings - The findings show that all identified BP except one (shadow innovation) is directed toward an increased emphasis on efficiency (exploitation) rather than innovation (exploration). With the increased demand for innovation capabilities in the public sector, this is identified as a problem.

Research limitations/implications - The limitations identified are related to the choice in the method of an interpretative case study, with issues of transferability and empirical generalizability as the main concerns. The implications for research are related to a need for additional studies into the enactment of digital ambidexterity, where the findings offer insight and inspiration for continued research.

Practical implications - The study shows that managers and executives involved in the design and imposition of governance within the public sector need to take the design recommendations for digital ambidexterity into consideration.

Social implications - The study offers two main implications for practice. First, policymakers need to take the conceptual distinction of efficiency and innovation into account when designing policies for the digital government. Second, existing funding practices need to be re-designed to better facilitate innovation.

Originality/value - This is the first study directed toward enhancing the insight into BP for digital ambidexterity in the public sector. The study has so far resulted in both a localized shift in policy and new directions for research. With the public sector facing needs for increased innovation capabilities, the study offers a first step toward understanding how this is currently counteracted through governance design.
\end{abstract}

Keywords Governance, Public sector, Digital ambidexterity, Balancing

Paper type Research paper

(C) Johan Magnusson, Tero Päivärinta and Dina Koutsikouri. Published by Emerald Publishing Limited. This article is published under the Creative Commons Attribution (CC BY 4.0) licence. Anyone may reproduce, distribute, translate and create derivative works of this article (for both commercial and non-commercial purposes), subject to full attribution to the original publication and authors. The full terms of this licence may be seen at http://creativecommons.org/licences/by/4.0/ legalcode 


\section{Introduction}

Current research acknowledges the existence of a dual approach to digitalization. On the one hand, digitalization involves the automation of menial labor and the replacement of human agency with the material agency through, for example, algorithms and robots (Ekbia and Nardi, 2017; Ranerup and Henriksen, 2019). On the other hand, it involves the radical redesign of purpose, value propositions and roles, within what is intermittently referred to as digital transformation, digital disruption and digital innovation (Hinings et al., 2018; Kromidha and Córdoba-Pachón, 2017). In line with previous research, we posit that these two approaches constitute distinguishable logics (efficiency versus innovation) that coexist and sometimes clash with each other (Xue et al., 2012).

The idea of a coexistence of parallel logics is one of the cornerstones of the field of organizational ambidexterity (Raisch and Birkinshaw, 2008). According to March (1991), organizations need to be involved in both continuous exploitation of existing opportunities and, exploration of new opportunities. In line with Benner and Tushman (2003), we equate exploitation with efficiency, through seeing it as continuous improvements of existing services and processes. Exploration is, respectively, equated with innovation through seeing it as activities for the acquisition and development of radically new knowledge and services.

Much of the early literature on ambidexterity focused on the optimal balance between these two activities (Birkinshaw and Gibson, 2004; O'Reilly and Tushman, 2008). This balance was supposed to be ascertained through different configurations and designs, such as the structural/functional separation of exploration and exploitation activities, i.e. structural ambidexterity (O'Reilly and Tushman, 2008) or the temporal shift between exploration and exploitation in the same function, i.e. contextual ambidexterity (Gibson and Birkinshaw, 2004). With the optimal balancing point being contingent upon the level of dynamism in the environment (Levinthal, 1997; Stieglitz, Knudsen and Becker, 2016), organizations need to be equipped with the ability to rebalance over time as changes occur (Luger et al., 2018).

Public sector organizations have been criticized for being poised in governance signified by a high level of bureaucracy, centralization and formal control (Mergel et al., 2018). As the argument goes, this makes them insulated against changes in the outside environment, increasing the risk of inertia and missed opportunities. The emergent literature surrounding adaptive governance (Hong and Lee, 2018; Wang et al., 2018; Janssen and van der Voort, 2016) and agile government (Mergel et al., 2018; Soe and Drechsler, 2018) push for a necessary balancing toward a higher level of flexibility, i.e. a stronger emphasis on innovation. This is also supported by an emergent stream of literature calling for increased innovation capabilities in the public sector (Mergel et al., 2018; Kankanhalli et al., 2017; Scupola and Zanfei, 2016; Meijer, 2015).

We argue that, in lieu of increased digitalization, public sector organizations need to be equipped with digital ambidexterity, i.e. "[...] the simultaneous handling of established business activities and rapidly changing new digital activities" (Piccinini et al., 2015, p. 12). Albeit taken from a study of the automotive sector, we argue that this definition is equally relevant for the public sector. Furthermore, this parallel strives for efficiency and innovation needs to be continually balanced in relation to the level of dynamism in the outside environment (regulative, technological, competitive, etc.), whereby we need additional insight into how organizations within the public sector balance efficiency and innovation in digital initiatives. 
On the basis of this, the following research question that this study aims to answer is:

$R Q 1$. How do public sector organizations balance efficiency and innovation in their digital initiatives?

The question answers the call for research by Mergel et al. (2018) on the combination of agile governance within traditional command-and-control structures in government, Janssen and van der Voort (2016) on adaptive governance through decentralized mandate and Zimmermann et al. (2018) on ambidextrous balancing practices (BP). The study was conducted as a single case study (Yin, 1989) in a large public agency in Sweden. A combination of fieldnotes, secondary material and interviews was used as a mode of data collection and the empirical work was conducted in 2017/2018.

The results involve empirical identification and analysis of ambidextrous BP in the target organization. The analysis revealed a bias of the BP toward efficiency, despite the initially recognized need for more innovation. The study contributes to both an empirical account of how information technology (IT) governance within the public sector balances between efficiency and innovation in digital initiatives and through insight into what we pose is a necessary redesign of IT governance toward increased digital ambidexterity. In addition, we present logically derived design recommendations for adaptive governance of digital ambidexterity in the public sector.

The remainder of the paper is organized accordingly. After this brief introduction, we revisit some of the precursory findings in relation to governing digital innovation and digital ambidexterity in Section 2. This is followed by the method in Section 3 and the results of the study, where the identified BP are described and analyzed in Section 4. The paper ends with a discussion in Section 5 where we elaborate on the findings in relation to previous calls for research and present the logically derived recommendations for adaptive governance, along with an elaboration of how the findings impact research and practice alike.

\section{Precursory findings and theoretical framing}

\subsection{Governing digital innovation}

The literature on digital innovation can be seen as an attempt to sensitize the influx of digital elements in everyday life. Previous conceptions highlight the digital as something separate, i.e. not assemblages as advocated by the work of Orlikowski and Scott (2008). This results in digitalization becoming equated with the shift from analog to digital. As noted by Yoo, Henfridsson and Lyytinen (2010), this is part of digitalization but not the complete picture. According to Hinings et al. (2018, p. 10), digital innovation deals with the "concerted orchestration of new products, new processes, new services, new platforms or even new business models." This is an expansion of previous definitions, which more emphasized the digital element in new products (Yoo et al., 2010).

Research in digital innovation has received a significant increase in scholarly attention during the past decade. Starting out with foundational research in the late noughties (Yoo et al., 2010), digital innovation has today become a burgeoning field within information systems (Nambisan et al., 2017). At the core of the movement lies the interest into what and how digital materiality brings changing prerequisites to incumbents and challengers alike (Svahn et al., 2017; Selander and Jarvenpaa, 2016; Svahn and Henfridsson, 2012). Digital innovation is acknowledged as being associated with a new logic for the way in which innovation is governed and managed. However, normative findings in terms of how governance should be designed to facilitate a fruitful conciliation of the clash are still lagging (Nambisan et al., 2017, 2019; Cannaerts, Segers and Warsen, 2019; Magnusson et al., 2020). 
Nambisan et al. (2017) identify the conceptual elements of the governance of digital innovation. The rationale behind this lies in a necessity for understanding how the governance of digital innovation ushers in different prerequisites than traditional innovation. The conceptual elements are presented in Table 1.

As observed, the logic of digital innovation challenges traditional perceptions of economies of scale through centralized organization and control and opens up for a new take on the boundaries of the organization. At the same time, temporality and intentionality is off-set, where the generative nature of the digital challenge's traditional logic (Zittrain, 2006). The ideas presented by Nambisan $\mathrm{et}$ al. (2017) are well aligned with the adaptive governance as suggested by Janssen and van der Voort (2016), where new stakeholders and increased externalization of previous internal activities calls for a new approach to governance.

\subsection{Digital ambidexterity}

The parallel attainment of two different organizational goals has been studied within the field of organizational ambidexterity (March, 1991; Benner and Tushman, 2003; Smith and Umans, 2015; Peng, 2019). The field traces its main roots back to the works of March (1991) in his study of organizational learning. Here, organizations are regarded as poised in a constant balancing between the exploitation of existing opportunities and the exploration of new opportunities. More recent studies have identified organizational ambidexterity as a driver of performance and a necessary prerequisite for success, i.e. a dynamic capability (Birkinshaw et al., 2016; Gieske et al., 2019).

\begin{tabular}{|c|c|c|}
\hline $\begin{array}{l}\text { Conceptual } \\
\text { elements }\end{array}$ & Description & Consequence \\
\hline $\begin{array}{l}\text { Dynamic } \\
\text { problem- } \\
\text { solution design } \\
\text { pairing }\end{array}$ & $\begin{array}{l}\text { Digital innovation management as a } \\
\text { sporadic, parallel and heterogeneous } \\
\text { generation, forking, merging, termination } \\
\text { and refinement of problem-solution design } \\
\text { pairs }\end{array}$ & $\begin{array}{l}\text { Acknowledges the fluid boundaries of the } \\
\text { innovation space and the potential for } \\
\text { innovation agency to be distributed }\end{array}$ \\
\hline $\begin{array}{l}\text { Socio-cognitive } \\
\text { sensemaking }\end{array}$ & $\begin{array}{l}\text { Shared cognition and joint sensemaking as } \\
\text { critical elements of digital innovation } \\
\text { management; "narratives" (embedded in } \\
\text { digital artifacts and supported by digital } \\
\text { technologies) as a vehicle for such socio- } \\
\text { cognitive sensemaking }\end{array}$ & $\begin{array}{l}\text { Acknowledges the fluid boundaries of the } \\
\text { innovation space and the heterogeneous } \\
\text { actors that populate it (distributed } \\
\text { innovation agency) }\end{array}$ \\
\hline $\begin{array}{l}\text { Technology } \\
\text { affordances and } \\
\text { constraints }\end{array}$ & $\begin{array}{l}\text { Considers digital technology use as sets of } \\
\text { affordances and constraints for particular } \\
\text { innovating actors and helps explain how } \\
\text { and why the "same" technology can be } \\
\text { repurposed by different actors or has } \\
\text { different innovation outcomes in different } \\
\text { contexts }\end{array}$ & $\begin{array}{l}\text { Acknowledges the receding distinctions } \\
\text { (and the accompanying duality) between } \\
\text { innovation processes and outcomes }\end{array}$ \\
\hline Orchestration & $\begin{array}{l}\text { Problem-solution matching as a micro- } \\
\text { foundation of digital innovation } \\
\text { orchestration; increasing the role of digital } \\
\text { technologies in enabling or supporting such } \\
\text { orchestration }\end{array}$ & $\begin{array}{l}\text { Acknowledges the fluid boundaries of the } \\
\text { innovation space and the potential for } \\
\text { innovation agency to be distributed }\end{array}$ \\
\hline
\end{tabular}

Source: Nambisan et al. (2017) 
In a recent longitudinal study of the insurance industry, Luger et al. (2018) found two different patterns emerging. Using environmental dynamism as a contingent variable, the findings suggest that organizations working in stable environments (incremental change) should focus on maintaining ambidextrous balance to drive long-term performance. For organizations working in unstable environments (discontinuous change), an ambidextrous balance needs to be dynamic, i.e. shifting in terms of emphasis on exploitation or exploration over time. As noted by Janssen and van der Voort (2016), the government could be seen as entering a more unstable environment, calling for an increased need for dynamic balancing.

These findings add to the plethora of research on how organizations should govern their ambidextrous balance over time (Luger et al., 2018; Zimmermann et al., 2018). At the same time, it opens up for a conceptual quagmire where the juxtaposing of exploitation and exploration implies treating it as a dichotomy rather than a dualism (Farjoun, 2010; Ask et al., 2015). In the strive for the coexistence of said two states, ambidextrous governance becomes laden with paradox (Smith et al., 2016) and perspectives such as the punctuated equilibrium model (Burgelman, 2002; Levinthal and March, 1993; Gregory et al., 2018) have been proposed as alternate theoretical approaches.

With the increased influx of digitalization in the private and public sectors alike, digital initiatives need to be balanced in relation to efficiency and innovation (Magnusson et al., 2017, 2020). We follow Pinnocault et al. (2017) in referring to this capability as digital ambidexterity. As noted by Zimmermann et al. (2018) and Luger et al. (2018), this capability furthermore requires BP that is instrumental in temporarily and iteratively achieving optimal balance. Despite ambidexterity having received a substantial amount of interest from the research community during the past couple of years, there is still a dearth of research into said BP (Zimmermann et al., 2018; Montealegre et al., 2019; Palm and Lilja, 2017; Cannaerts, Segers and Warsen, 2019; Magnusson et al., 2020). More so, the prevailing perspective is still one of punctuated equilibrium, i.e. the assumption of steady states. This is particularly visible in the work of Luger et al. (2018), where the notion of rebalancing implies a shift from one emphasis to another. Our approach stands true to the idea of balancing, i.e. being a continuously ongoing process.

Despite that the majority of both foundational and extant literature on ambidexterity has been associated with empirical studies of the private sector, there is a growing body of literature hailing from the public sector. As seen in Cannaerts et al. (2019) and Palm and Lilja (2017), the theory of organizational ambidexterity is deemed transferable to the public sector. Peng (2019) explores the transferability of organizational ambidexterity into public non-profit organizations and finds that the theory is potent in allowing researchers to better understand the tensions hailing from multiple stakeholders varying expectations. This conclusion is also supported by e.g. studies of local governments in Smith and Umans (2015).

\section{Method}

For this study, we conducted a case study in a single organization, as our research aimed at a holistic understanding of a relatively complex phenomenon, ambidexterity balancing, within a real-life context (Yin, 1989). The agency in question (Social Insurance Agency, SIA) was selected based on convenience and access, while we could argue that it represents a rather rare case with the potential for revelatory elements (Yin, 1989) of the emerging phenomenon of ambidextrous balancing, as the need for that had been readily recognized in the organization's management. The study was commissioned by the agency itself, i.e. funded directly by the agency. SIA (Försäkringskassan in Swedish) has 14,000 employees
Empirical
evidence of a
bias

63 
TG

15,1

64

and an IT organization comprising 900 employees, with a yearly budget of $€ 160 \mathrm{~m}$ (www. forsakringskassan.se).

To answer the research question, the case study was geared toward increasing our understanding of how digital ambidexterity is currently governed within the organization. This was operationalized through collecting both secondary data, surveys and interviews (see below for more details) with a focus on IT governance.

The primary data includes 13 semi-structured, $1 \mathrm{~h}$ interviews with middle-to-senior management. Following Zimmermann et al. (2018), we excluded executive managers such as the chief executive officer (CEO). The rationale for the quantitatively rather limited selection of interviews in a large organization was a strive for reaching an empirical saturation point, i.e. not something that was a-priori set when initiating the study. The researchers continually assessed the added value of each new interview and after reaching the empirical saturation point (i.e. no significant new empirical insight gained from additional interviews), the interview study was concluded.

The interviews took place during September-November 2017. They were recorded and transcribed shortly thereafter (Table 3). The appendix reports the thematic questions addressed in the interviews. Secondary data involved documents in the form of governance steering documents, consulting reports, financial reports and project charters (Table 2), which helped us to understand the context, espoused values and strategies and the types and scales of development initiatives within SIA. Secondary data were also used to identify informants and to ensure the stakeholder representativeness for the interviews (Table 3).

The data analysis involved sequential steps. First, in approaching the empirical material, we conducted thematic analysis (Aronson, 1995) to find categories of the practice of balancing between efficiency and innovation. Through multiple iterations of coding, we identified 13 distinct BP based on our interpretations of the interviewee's expressions (Walsham, 1995). These observations were then structured following Nambisan et al.'s (2017) conceptual categories, resulting in an overview of BP that either pushed the scale toward more efficiency or more innovation. Following this, we identified further secondorder constructs (governance, continuity, culture, power and selection; Figure 1) upon the observed BP. The secondary material was used to sensitize ourselves to the organization

\begin{tabular}{llc}
\hline Data source & Description & Amount \\
\hline Meetings & $\begin{array}{l}\text { Introductory meetings } \\
\text { Workshop for deepening the problem } \\
\text { understanding }\end{array}$ & 2 \\
$\begin{array}{l}\text { IT governance } \\
\text { steering documents } \\
\text { Consulting reports }\end{array}$ & $\begin{array}{l}\text { configuracuments detailing the current } \\
\text { Consulting reports directed toward IT } \\
\text { governance oversight and redesign } \\
\text { Accumulated yearly (2017) figures with the } \\
\text { total spend, budgets, etc. for each project }\end{array}$ & 7 \\
Financial reports & $\begin{array}{l}\text { Formal documents focused on describing } \\
\text { and defining development and maintenance } \\
\text { projects' scope, stakeholders, team and } \\
\text { objectives } \\
\text { 1-2h each with individuals (Table 3) } \\
\text { involved in project portfolio management, } \\
\text { general IT governance and project } \\
\text { management }\end{array}$ & 9 \\
Interviews & & 96 \\
\hline
\end{tabular}

Table 2.

Overview of data collected

$$
\text { management }
$$




\begin{tabular}{|c|c|c|c|}
\hline Respondents & Title & Function & $\begin{array}{l}\text { Empirical } \\
\text { evidence of a }\end{array}$ \\
\hline 1 & Chief architect & IT & bias \\
\hline 2 & Innovation hub manager & IT & \\
\hline 3 & Project leader & Health insurance & \\
\hline 4 & Project leader & Disability & \\
\hline 5 & Development strategist/portfolio manager & Family & \\
\hline 6 & Development strategist/portfolio manager & Migration & 65 \\
\hline 7 & Line manager & Business support & \\
\hline 8 & Line manager & Line support & \\
\hline 9 & Department head & CEO support & \\
\hline 10 & Business developer & Development staff & \\
\hline 11 & Business developer & Development staff & Table 3. \\
\hline 12 & Business developer & Development staff & Overview of \\
\hline 13 & Controller & Development staff & respondents \\
\hline
\end{tabular}

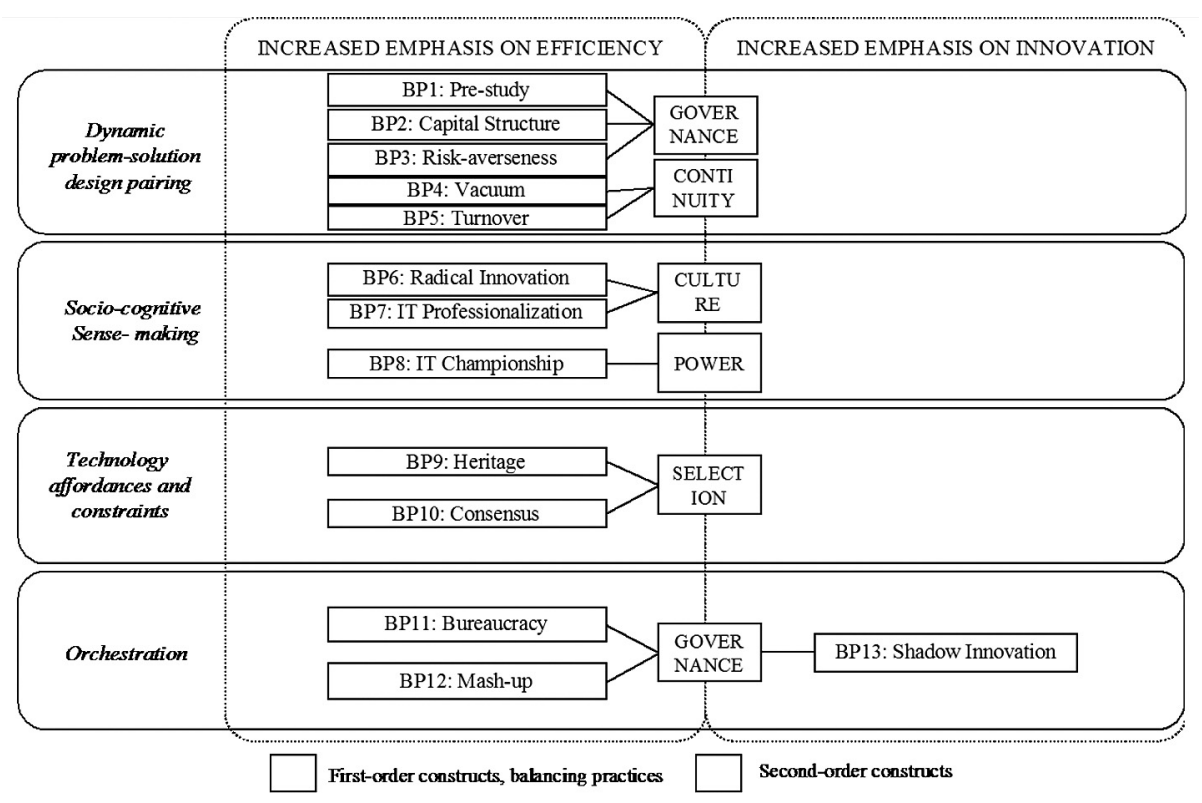

Figure 1. Overview of $\mathrm{BP}$ in SIA

and to the BP and balance and allow for deeper insight into the context where the interviews were conducted.

Second, the framework for IT governance developed by De Haes and Van Grembergen (2009), consisting of structures, processes and relational mechanisms, was used as a basis for our theorizing on design implications toward more balanced innovation management (according to the conceptual elements of digital innovation management by Nambisan $e t$ al., 2017). This analytical work involved inspiration from affordance theory and sociomateriality (Leonardi, 2011) in stipulating design implications that, respectively, afford and constrain outcomes of required BP. The work involved iterating between our 


\section{Results: The balancing practices of the social insurance agency}

In order for us to stay with the times and be relevant for our citizens, it is about fulfilling our mission. The state's value base and achieving the intentions of the politicians. And we should do this in an efficient manner. If we are to be able to do this in the future [...] and if we continue to solely pursue efficiency, then we will [...] become extremely cost-efficient, and extremely irrelevant $[\ldots .$.$] so we need to reallocate all the time, to innovation. Business developer.$

As seen in the opening quote, the agency acknowledges the tensions and potential trade-offs between innovation and efficiency in digital initiatives. There is a sound understanding that this position is problematic and that a continued sole focus on efficiency will risk resulting in obsoleteness, i.e. that there is a need to rebalance toward increased innovation. The remainder of the results is structured following Nambisan et al.'s (2017) four conceptual elements of digital innovation management, to create an overview of the BPs identified in the case.

\subsection{Dynamic problem-solution design pairing}

The BPs found within the dynamic problem-solution design pairing were identified as directed toward increasing the emphasis on efficiency. In terms of governance (i.e. processes, structures and relational mechanisms for control) as a second-order construct, the BPs involved an overemphasis on the role of pre-studies (BP1), a constraining capital structure (BP2) and a bloated risk averseness (BP3).

SIA is dominated by a highly evolved and intricate use of pre-studies that are compulsory before starting a formal project. The pre-studies are designed to identify potential risks involved in the projects and without these risks being deemed as acceptable the project will not be started. Instead, we saw numerous examples of project ideas that got stuck in a limbo of pre-study after pre-study.

$[\ldots][\ldots]$ but that's the way they do it here, a lot of focus on the pre-study, that is a lot of analysis on the pre-study. You tend to get stuck here quite a lot [. . . Innovation Hub manager.

The institutionalized use of pre-studies to avoid risk leads to all formally prioritized projects having to be geared toward achievable, risk-free and short-term benefits. This bloated riskaverseness creates an additional balancing toward efficiency rather than innovation, where innovation-related initiatives are avoided.

[...] [...] we can't start if we can't describe the benefits first and that is [...] for big innovation initiatives, that become highly theoretical. We do not really know until we have tried it in some form of proof-of-concept or in an innovation laboratory or something. We would need to do it, so it becomes like 'But let's go for the safe option'. This is something we can describe an effect for. Portfolio manager.

In addition to these two identified practices of balancing, the regulatory aspects of funding development initiatives become a third practice of balancing toward efficiency. According to the Swedish Government, all development initiatives have to be funded through loans. Because of this, it would have to be possible to turn the results of the initiatives into immaterial assets and include them in the balance sheet. In other words, the risk is impossible to handle without being non-compliant with accounting standards.

The biggest part (out of the development budget) is funded through loans, and then it is really important that this results in a productivity increase so that we get something out of it [...]. 
Because it turns into a cost that we need to handle. And this has gotten a lot more focus during the last years [... .] Well, how can we get a development plan in balance? We need to have a certain amount of financial revenue to get it in balance. Controller.

In terms of continuity (i.e. stable continuation of prerequisites for operations over time) as a second-order construct, the identified BPs involved a vacuum of political goals (BP4) and a high turnover of CEO/board (BP5). With SIA governed by letters of instruction from the Swedish Government, the agency receives annual additions to its tasks and responsibilities. At the same time, the constitution states that no new tasks and responsibilities may be added without additional funding being provided by the state. Hence, there is relative stability in terms of the tasks and responsibilities over time. In parallel with this, the government communicates more broadly in terms of overarching objectives for the Swedish public sector in general. Starting from 2015, the government has had the bold ambition to become the best in the world in using the benefits of digitalization. This has, unfortunately, not been amply translated into tasks and responsibilities for the individual agencies; hence, digitalization is necessary for the agencies to handle within the boundaries of their existing budgets.

You see, the Minister of Interior says that: 'now all the agencies should be digitalized' [. . . I mean, I am not sure if that gets you motivated [. . . B Business developer.

As digitalization is supposed to be handled within the confines of the existing tasks, responsibilities and budget, the only available option for the agency lies through increased efficiency. Only through first making the necessary investments into increased efficiency can the agency free up the necessary capital to push for more innovation-oriented initiatives. Working on a yearly budget, this facilitation of innovation is basically impossible; hence, the vacuum of political goals becomes a balancing practice for increased emphasis on efficiency.

At the same time, the political system involves the political assignment of CEOs at the head of all agencies. With elections being every fourth year, this results in the average timespan for a CEO (and coincidentally also the board) being just under four years. This creates a situation where the overarching prioritization of the agency's focus (within the confines of the task and responsibility) will fundamentally change every four years. The relative short timespan creates a situation where innovation-oriented benefits will be hard to realize; hence, the CEOs will instead focus on short-term efficiency gains as their primary objective.

And depending on which CEO comes in they have different demands and desires in terms of how you delegate responsibility and how much control they wish to have themselves. I have experienced two CEOs. They have positive and negative sides, both of them. But primarily they are each other's opposites. My arms are not wide enough to describe those extremes. They are entirely different as people. With entirely different needs or desires in terms of scope of control. Line manager.

Related to Nambisan et al. (2017), the existing BP directly counteract the dynamic problemsolution design pairing through solidifying the centralization of innovation activities. The boundaries of the innovation space are kept under strict formal control and the distribution of agency is deterred.

\subsection{Socio-cognitive sensemaking}

The BPs found within the socio-cognitive sensemaking were identified as directed toward increasing the emphasis on efficiency. In terms of culture (i.e. the shared values, goals and
Empirical
evidence of a
bias 
practices of the organization) as a second-order construct, BPs involved a fear of radical innovation (BP6) and professionalized IT (BP7).

With the agency's budget funded through taxation, there is a core belief that the agency needs to handle its funds in a responsible manner. Risk, in this instance, is equated with doing something that falls outside the safeguarded mission of the agency, i.e. all explorative activities are deemed misaligned with the code of conduct. Experimentation becomes highly questionable for the organization.

Well, that we should have some sort of experimentation factory [...] Is that really what the SIA should be doing? [ . . . but that is really more of a political question [ . . . Controller.

In addition, the past couple of years has seen an increase in IT professionalization. This is explained as having been necessary to fill a void of order, alleviating a situation where there was a significant lack of control associated with IT costs and activities. The solution has been a significant and continuous formalization of IT governance and control, resulting in a situation where the organization and their demands, are being met by a highly professionalized IT staff, fundamentally following strict processes to counteract risk under the guise of increasing their level of professionality. At the same time, the IT staff lacks a fundamental understanding of the business that would be necessary.

We have a very strong IT organization. Competent, good, industrious, want and can do. Unfortunately, I guess some parts of the IT organization think that they understand the business to a much higher extent than what they actually do. Line manager.

This shift toward increased professionality with IT also has significant implications for the shift in power in the organization.

$[\ldots][\ldots]$ we have very weak knowledge in terms of IT development [. . . ] and then you are in the hands of those that come with the suggestions. Line Manager.

The increased level of IT championship (BP8), partly as a consequence of lagging digital competence on the business side, leads to an increased emphasis on efficiency rather than innovation. With the IT organization solely measured on financial performance (efficiency), they will stack necessary investments in underlying infrastructure into the businessoriented projects. This further shifts the focus of the projects away from potential innovation to alleviating deficiencies in the underlying infrastructure.

We have shortages in competence when it comes to both governing and managing development on the business side, which results in IT stepping in and taking responsibility where they should not [...] Our biggest problem concerns IT sneaking in a platform change, a technology that drives development linked to the needs that they see. But if you do that tucked away in the overarching business development projects [...] I think we allocate much of the development budget on this type of technology debt [...] I would like it to be a little more transparent.

Line manager

Related to Nambisan et al. (2017), the BPs identified counteract the socio-cognitive sensemaking by cementing the functional units of the organization rather than acting for increased fluidity of boundaries for innovation. In terms of the innovation agency, this is centralized, counteracting distributed socio-cognitive sensemaking per design.

\subsection{Technological affordances and constraints}

The BPs found within the technological affordances and constraints were identified as directed toward increasing the emphasis on efficiency. In terms of selection (i.e. patterns of 
how initiatives are selected) as a second-order construct, BPs involved a constraining digital heritage (BP9) and consensus (BP10).

SIA identifies that there is a high degree of short-sightedness in its identification and selection of new projects. One result of this is the continued deprioritization of infrastructural investments, where (as previously noted) changes in infrastructure are not treated as investments in their own right but bundled into existing projects.

January 1 , there is still a lot to do until the new yearly period. So, it becomes very short-sighted and fidgety, and, if we consider that we have governed agencies like that for the past 20 years, the architecture is one bloody bowl of spaghetti, because we always need to go for the short-sighted solutions. Business developer.

This creates a situation where the emergence and modernization of infrastructure and architecture is treated $a d$ hoc, resulting in a severely constraining and less than purposeful digital heritage. As the underlying logic of the lion's share of investments that get prioritized is one of increased efficiency, investments in modernizing the infrastructure cannot be amply handled in the existing setting.

In addition, there is an underlying feeling of innovation being risk-related not only solely in terms of the investments per se but also politically. As seen in the quote below, the Innovation hub manager has struggled to push innovation at the expense of political cost. This creates a situation where potential innovation requires consensus, something that is difficult to achieve; hence, this leads to a constraint for new ideas and selections.

I have tried now, with two mobile apps already [...] the first nobody wanted, because you had stepped on the wrong toes [. . .] that made me learn. Everybody needs to be on board [ . . .] but all can't [...] they would become too many [...] so many people will have issues when it is time for implementation. Innovation hub manager.

In relation to Nambisan et al. (2017), the case illustrates the inability of the organization to handle the receding distinctions between processes and outcomes of innovation. The effect of not being able to do this, results in a continuous deprioritization of investments in infrastructure, with the results of growing constraints associated with the digital heritage. The need for consensus and the use of this as a foundational element in prioritization also counteracts innovation.

\subsection{Orchestration}

All BPs but one found within orchestration were identified as directed toward increasing the emphasis on efficiency. All practices were related to the second-order construct of governance and included bureaucratization (BP11), a mashup of development and maintenance (BP12) and shadow innovation (BP13). Out of these, shadow innovation comprises the sole innovation-focused balancing practice identified in the case.

The respondents all see themselves and the organization as poised in a stern bureaucracy. This bureaucracy does not limit itself to the delivery of services to the citizens but is also highly prevalent in the internal organization of functions such as digital development.

It can be that some managers dismiss suggested changes [...] but it can also be that our [development] processes are so bureaucratic that you lack the energy to hammer new suggestions through. Project manager

Here we see that the high level of formalization and the aspiration for the economically sound organization of development counteracts agility and, in turn, innovation. For an individual working in the organization, the bureaucracy counteracts change. 
In parallel with this, we found strong evidence of a significant bias toward efficiencyoriented projects. Increased efficiency is deemed as the primary rationale for new projects and as such the only legitimate and justifiable reason for initiating a new project.

Practically all projects are focused on efficiency effects, measuring FTEs. That hinders a lot if one is supposed to be innovative. Project manager

This precedence of increased efficiency over innovation is problematic, as the agency functions with a fixed annual budget for development. With an increased number of projects directed toward efficiency, the available funds for innovation projects are depleted. Hence, orchestration is set on a fixed path where innovation is made impossible provided the narrow confines of the development budget.

In addition to these issues of bureaucracy, the systems development and maintenance processes of the agency along with their funding, resulting in a situation where development is neither defined nor allowed. The result of this is that corrective maintenance, compliance and other aspects traditionally related to maintenance are pushed into the development budget as sub-projects for development projects. Further, as these activities are devoid of innovation (i.e. focused on exploiting existing opportunities) they steal resources from the development budget when they should have been part of the maintenance budget.

$[\ldots][\ldots]$ it is pure maintenance to update that service [...] that is not development. But since we have a funding model that says it is development, then we believe it is development. Portfolio manager

In other words, the inability to delineate and isolate maintenance from development results in a balancing practice directed toward increased efficiency.

In contrast with the aforementioned BPs directed toward increased efficiency over time, we also identified a single balancing practice for increased innovation. We refer to this balancing practice as shadow innovation, as it captures unsanctioned innovation activities conducted in the organization.

It becomes a bit like guerilla warfare [. . . IT-departments have always found cool, good things, and it easily becomes technology-driven [.. . ] it is shadow innovation [...], Business developer.

As described in the quote above, said activities are often technology-driven and poised in the organization as a form of guerrilla tactics. The rationale is that the existing governance does not cater to (either through lacking agility or lacking resources) swift actions that explore new opportunities in a dramatically changing technological landscape.

One cannot have an innovation budget [in the public sector] and say that we get nothing out from $80 \%$ but this $20 \%$ will become so bloody good. It is not possible. So, risk acceptance is zero, and how does that then result in innovation? Then the IT department needs to do a lot of things under the radar. Business developer.

With the existing governance geared toward efficiency rather than innovation, the agency's actors need to act under the radar, i.e. in the shadows of control to facilitate innovation. As described above, the inability of the organization to handle risk becomes the driving force for shadow innovation. The inability of accepting risk, with the risk being equated with the height of innovation, also becomes an inability to pursue innovation. With the coworkers understanding that innovation is necessary for the long-term relevance of the agency, they will pursue other avenues to achieve innovation.

In relation to Nambisan et al. (2017), shadow innovation acts as an informal control in orchestrating digital innovation. With bureaucracy and a mashup of the development process counteracting digital innovation (in the form of distributed agency etc.), it also 
drives the existence of shadow innovation. With shadow innovation being a response to the high level of formalization in the digital development process, this response in shifting from formal to informal control requires additional attention.

\section{Discussion}

Figure 1 contains a summary of the identified first and second-order constructs, i.e. the BPs identified in the case.

What emerges from the findings is a set of BPs geared toward increasing the emphasis on efficiency at the expense of innovation. In other words, all but one of the identified BPs counter-act the strive for increasing the emphasis on innovation within the public sector, challenging the notion of digital ambidexterity and foreboding a continuous increase of efficiency.

\subsection{On the dearth of balancing for innovation}

As noted in the results, all but one of the identified BPs were found to be geared toward an increased emphasis on efficiency rather than innovation. As noted by Mergel et al. (2018), this may constitute a fundamental challenge for organizations experiencing a need for increased innovation capabilities. In relation to previous studies by Zimmermann et al. (2018) and Luger et al. (2018), the focus is not on the shift between different modes (exploit/ explore), but rather on a continual balancing. The discussion is organized following the conceptual elements as identified in Nambisan et al. (2017), presented in Table 1.

In terms of the dynamic problem-solution design pairing (i.e. the management of digital innovation involving heterogeneous and iterative refinement of problem-solution pairings), the findings show that the BPs were related to governance and continuity. Governanceinvolved BPs associated with existing legislation related to capital structure, translated into a necessity for pre-studies to mitigate all risk from the prospective digital initiatives. These practices push the balance into an increased emphasis on efficiency rather than innovation, where significant hurdles for innovation are put in place by governance and regulation. To complement these BPs, notions related to a lack of continuity driven by high CEO turnover and a vacuum of long-term political goals additionally push the balance toward increased emphasis on efficiency. Hence, dynamic problem-solution design pairing is counteracted by existing governance and a lack of continuity.

In terms of the socio-cognitive sensemaking (i.e. the shared cognition and joint sensemaking, often facilitated by narratives infused in digital artefacts), culture and power distribution drive a continuous focus on efficiency rather than innovation. With a strong culture that equates radical innovation with a less than conscientious handling of tax funds, balancing pushes for continuous improvement (efficiency) rather than innovation. In addition, a growing professionalization of IT has resulted in a shift away from risk-taking to risk-mitigation, where the IT professionals have created governance that will push risk to other sides of the organization rather than the IT department (Magnusson and Bygstad, 2013). This results in an uneven power distribution, where the business side is subject to IT governance rather than agents in it. The uneven distribution of power results in the organization accepting a balancing toward efficiency, as it mitigates risk.

In regard to technology affordances and constraints (i.e. the context-sensitive manner in which technology yields different outcomes), selection drives an increased emphasis on efficiency. The constraining digital heritage in the form of existing infrastructure is laden with path-dependencies and lock-in effects (Rolland et al., 2018) and existing governance acts to push any attempt at modernization to an ad hoc basis. This results in most types of foundational investments in infrastructure being squeezed into existing projects under the
Empirical
evidence of a
bias 
guise of necessary prerequisites for the project, instead of treated as long-term investments into a more flexible infrastructure (Janssen et al., 2009). In parallel with this is the practice of consensus, where adoption and benefits realization of a digital initiative is dependent upon a political process of getting everybody onboard, similarly shifts the emphasis to efficiency. With the decentralization of mandate over adopt/discard to middle management, this can be seen as problematic for the purposive diffusion of innovations in the organization. The result is the aforementioned decentralization of mandate that without appropriate governance, risks acting counter-productively for innovation.

In terms of orchestration (i.e. problem-solution matching as a micro-foundation of digital innovation), governance acts to increase the emphasis on both efficiency and innovation. Orchestration is enacted in a context of bureaucracy, where the current organization and governance of the development function directly pushes an increased emphasis on efficiency. The development function is poised in a high level of formal control, with fixed budgets and without clear strategic objectives for balancing between efficiency and innovation. This results in the process of development being non-adaptive and primarily focused on achieving efficient development. This operational excellence approach to development may to some extent be necessary, but invariably counteracts aspirations for adaptive governance (Janssen and van der Voort, 2016), particularly when combined with the mash up practice where development and maintenance are convoluted.

In addition, we also found evidence of a singular practice for increased innovation. Coworkers in the organization have a general understanding of the necessity for innovation and given the existing governance setup, they shift to activism (Selander and Jarvenpaa, 2016) to achieve said innovation. We refer to this balancing practice as shadow innovation (see also Magnusson et al., 2020), as it is unsanctioned and happens in the shadows of control. It is not an example of a confrontation strategy (Janssen and van der Voort, 2016), but more a manner in which the coworkers can achieve limited and unscalable innovation within the current governance configuration. The downsides to this lie in the non-scalability and inefficiency through redundancy, i.e. an inability to find synergies and economies of scale in the distributed initiatives. As they are not made visible in the organization (outside of the department where they are conceived), they constitute a drain on resources.

The identified BPs within the conceptual categories of Nambisan et al. (2017) become entry-points for design-recommendations for governing digital ambidexterity, as we will address in the following chapter.

\subsection{Design recommendations for governing digital ambidexterity in the public sector}

As the opening quote of the result section illustrates, agencies are poised in the contortionist position of catering both to efficiency and innovation simultaneously. To concretize such strive for digital ambidexterity, we argue that adaptive governance is necessary. Table 4 contains a summary of the adaptive governance mechanisms, logically derived from the BP identified in the case study.

As seen in Table 4, the adaptive governance advocates a break with existing governance practice (particularly the recently proposed liberal model of IT governance as found in Leclercq-Vandelannoitte and Emmanuel, 2018). In terms of structures, the shift to a decentralization of innovation hinges on the colocation and job rotation of individuals involved with innovation activities, as well as the increased employment of externalized innovation practice. To facilitate scaling and to avoid suboptimization of the innovation outcomes, this places emphasis on the structures in place for adopting innovation outcomes. This corresponds to the strategies of self-organization and public-private strategies as presented in Janssen and van der Voort (2016). 


\begin{tabular}{|c|c|c|c|c|c|}
\hline \multirow[b]{2}{*}{$\begin{array}{l}\text { Conceptual } \\
\text { element }\end{array}$} & \multirow[b]{2}{*}{ Identified BPs } & \multicolumn{3}{|c|}{ Adaptive governance mechanisms } & \multirow{2}{*}{$\begin{array}{r}\text { Empirical } \\
\text { evidence of a } \\
\text { bias }\end{array}$} \\
\hline & & $\begin{array}{l}\text { Structures that } \\
{[\ldots]}\end{array}$ & Processes that $[\ldots]$ & $\begin{array}{l}\text { Relational } \\
\text { mechanisms that }[\ldots]\end{array}$ & \\
\hline $\begin{array}{l}\text { Dynamic } \\
\text { problem-- } \\
\text { solution } \\
\text { design pairing }\end{array}$ & $\begin{array}{l}\text { Vacuum, } \\
\text { turnover, pre- } \\
\text { studies, capital } \\
\text { structure and risk } \\
\text { averseness }\end{array}$ & $\begin{array}{l}\text { Afford: } \\
\text { decentralization of } \\
\text { innovation and } \\
\text { dialogue with } \\
\text { transparency }\end{array}$ & $\begin{array}{l}\text { Afford: analytical } \\
\text { separation of } \\
\text { efficiency/innovation } \\
\text { in terms of processes } \\
\text { for investment }\end{array}$ & $\begin{array}{l}\text { Afford: participation } \\
\text { of both internal and } \\
\text { external stakeholders; } \\
\text { empowerment of } \\
\text { individuals not }\end{array}$ & \\
\hline & & $\begin{array}{l}\text { Constrain: } \\
\text { centralization and } \\
\text { formalized } \\
\text { internal } \\
\text { procurement of } \\
\text { innovation(s) }\end{array}$ & $\begin{array}{l}\text { evaluation, } \\
\text { prioritization and } \\
\text { benefits realization } \\
\text { Constrain: blurring of } \\
\text { boundaries between } \\
\text { innovation and } \\
\text { efficiency }\end{array}$ & $\begin{array}{l}\text { originally perceived } \\
\text { as involved in } \\
\text { innovation } \\
\text { Constrain: } \\
\text { exclusiveness and } \\
\text { specialization/ } \\
\text { division of labor }\end{array}$ & \\
\hline $\begin{array}{l}\text { Socio- } \\
\text { cognitive } \\
\text { sensemaking }\end{array}$ & $\begin{array}{l}\text { IT championship, } \\
\text { radical innovation } \\
\text { and } \\
\text { professionalized } \\
\text { IT }\end{array}$ & $\begin{array}{l}\text { Afford: co-location } \\
\text { of individuals } \\
\text { with different } \\
\text { perspectives on } \\
\text { the organization } \\
\text { and its purpose, as } \\
\text { well as technology } \\
\text { Constrain: } \\
\text { functional } \\
\text { isolation and } \\
\text { simplification }\end{array}$ & $\begin{array}{l}\text { Afford: create shared } \\
\text { cognition and co- } \\
\text { created narratives } \\
\text { regarding successful } \\
\text { (and unsuccessful) } \\
\text { innovation initiatives } \\
\text { Constrain: the hiding } \\
\text { of failures and } \\
\text { initiatives that may be } \\
\text { deemed less } \\
\text { successful }\end{array}$ & $\begin{array}{l}\text { Afford: dissemination } \\
\text { of narratives both } \\
\text { within and outside the } \\
\text { organizational } \\
\text { boundaries } \\
\text { Constrain: } \\
\text { hierarchically induced } \\
\text { reporting structures } \\
\text { aimed at monitoring } \\
\text { and control }\end{array}$ & \\
\hline $\begin{array}{l}\text { Technology } \\
\text { affordances } \\
\text { and } \\
\text { constraints }\end{array}$ & $\begin{array}{l}\text { Risk averseness, } \\
\text { scaling, } \\
\text { development } \\
\text { processes and } \\
\text { digital heritage }\end{array}$ & $\begin{array}{l}\text { Afford: re-use and } \\
\text { scaling of digital } \\
\text { innovations } \\
\text { previously } \\
\text { developed within } \\
\text { or outside the } \\
\text { organizational } \\
\text { boundaries } \\
\text { Constrain: } \\
\text { tendency for "not } \\
\text { invented here" } \\
\text { syndrome }\end{array}$ & $\begin{array}{l}\text { Afford: the } \\
\text { identification and } \\
\text { selection of digital } \\
\text { innovation candidates } \\
\text { for scaling } \\
\text { Constrain: risk- } \\
\text { averseness for } \\
\text { incorporating and } \\
\text { scaling existing } \\
\text { technologies into new } \\
\text { solution space } \\
\text { Redundancies }\end{array}$ & $\begin{array}{l}\text { Afford: dialogue } \\
\text { between the } \\
\text { innovation vs } \\
\text { efficiency activities } \\
\text { that cater to } \\
\text { institutionalized } \\
\text { learning } \\
\text { Constrain: sub- } \\
\text { optimal incentives } \\
\text { that lead to } \\
\text { disenfranchising of re- } \\
\text { use }\end{array}$ & \\
\hline Orchestration & $\begin{array}{l}\text { Mesh, } \\
\text { development } \\
\text { overload, } \\
\text { governance } \\
\text { overload, } \\
\text { centralization, } \\
\text { formal control, } \\
\text { shadow } \\
\text { innovation }\end{array}$ & $\begin{array}{l}\text { Afford: } \\
\text { externalization of } \\
\text { sourcing of } \\
\text { innovation } \\
\text { Constrain: } \\
\text { increased } \\
\text { transaction - and } \\
\text { coordination costs } \\
\text { for external } \\
\text { sourcing of ideas }\end{array}$ & $\begin{array}{l}\text { Afford: dynamic } \\
\text { matching of supply } \\
\text { and demand of ideas } \\
\text { and innovation } \\
\text { Constrain: } \\
\text { Transactional } \\
\text { perceptions of } \\
\text { commoditized } \\
\text { innovation }\end{array}$ & $\begin{array}{l}\text { Afford: distinction } \\
\text { between value co- } \\
\text { creation and capture, } \\
\text { with clear } \\
\text { demarcations of } \\
\text { responsibility and } \\
\text { formalism } \\
\text { Constrain: blurring of } \\
\text { co-creation/capture } \\
\text { and consummate } \\
\text { responsibility tied to } \\
\text { single individual/ } \\
\text { function }\end{array}$ & $\begin{array}{r}\text { Table } 4 . \\
\text { Design } \\
\text { recommendations for } \\
\text { governing digital } \\
\text { ambidexterity } \\
\text { derived from the } \\
\text { study }\end{array}$ \\
\hline
\end{tabular}


In terms of processes, the analytical separation of efficiency and innovation is manifested in increased pluralism for investment prioritization, benefits realization and investment evaluation. Instead of trying to squeeze innovation initiatives into templates designed according to the efficiency logic, this requires new models and methods to be developed. At the same time, the analytical distinction between efficiency and innovation creates the basis for both shared understanding and, as a consequence thereof, narratives (Nambisan et al., 2017).

Regarding the relational mechanisms, the increased pluralism of both approach and sourcing (increased externalization) is mirrored into an increased number of stakeholders involved in governance. This requires a purposive distinction between value creation and value capture, as well as inclusion and empowerment of previously dispossessed individuals and actors, to adequately govern. In response to Wang et al. (2018), this perspective on value creation/capture may be used as a basis for identifying relevant stakeholders for more collaborative and inclusive governance. In relation to Janssen and van der Voort (2016), the increased emphasis on digital innovation increases the scope of stakeholders; hence, it calls for new ways in which to identify these to mobilize them.

This dynamic balancing will not, however, come without an associated cost. Said cost is primarily manifested in expected decreased efficiency gains for the public sector. In a situation where the dominant logic was one of exploitation (i.e. the traditional), all digital initiatives would at least in theory be coupled with efficiency gains. In a world where digital options are increasingly necessary (Sandberg et al., 2014; Rolland et al., 2018), future relevance for the public sector comes at a cost. In this perspective, governance needs to be stable enough to withstand simplified notions of short-term efficiency that will run the risk of down-prioritizing future benefits. The shift proposed in line with Nambisan et al. (2017) and Janssen and van der Voort (2016) will need to be robust, i.e. it should not be handled through interim and temporary configurations. The implications of this are substantial for the redesign of governance in a system that displays a low level of adaptability over time (Lapsley and Wright, 2004) and in light of ambidexterity design, which reportedly have been geared toward temporary solutions (Birkinshaw et al., 2016; Cannaerts et al., 2019).

\subsection{Conclusion}

The balancing practices in the public sector display a bias toward increased efficiency at the expense of innovation. Out of all identified balancing practices only one (shadow innovation) was found to increase the emphasis on efficiency rather than innovation. With the reportedly increased need for digital innovation capabilities in the public sector, as a response to increased environmental dynamism through digitalization, the identified bias is a substantial hinderance for digital ambidexterity in the public sector. To alleviate this shortcoming, this study proposes a set of logically derived adaptive governance mechanisms in line with Nambisan et al. (2017) and Janssen and van der Voort (2016). We argue that said changes in governance for increased digital ambidexterity need to be robust and need to coexist with the prevailing bureaucracy and formal governance as argued to be a hinderance to agility by Mergel et al. (2018).

Our study has three main implications for research. In line with Mergel et al. (2018) and Janssen and van der Voort (2016), we believe that our identification of BPs and particularly the bias in said BPs, offers a fruitful avenue for future research. Through empirically identifying and analyzing the BPs, we hope that this will be followed by additional empirical research into ambidextrous $\mathrm{BP}$ within the public sector. Here, our findings stand in contrast with those of Luger et al. (2018), where the notion of rebalancing involves a shift from exploration to exploit (or vice versa). Instead, we propose a gradual balancing, continuous 
over time. Second, we see the analytical equation of exploration with innovation and exploitation with innovation inspired by Benner and Tuschman (2003) as particularly valuable for future research. Through this discriminate handling of efficiency and innovation, research is provided with a method of inquiry that allows for an analysis of activities and a link between said activities and resources. This holds the possibility of creating a more in-depth analysis of alternate data sets such as discretionary budgets et cetera to drive findings within organizational ambidexterity. Third, our findings offer a means through which we can increase our understanding of the coexistence of bureaucracy and adaptive/agile governance as identified by Mergel et al. (2018). The BPs exist and offer a potential explanation to both the lag and path-dependencies within the increased adoption of agile practices within the public sector. Our study may be considered a step toward a more nuanced understanding of the constraints for agility within the public sector.

The main practical implication of the present research is that it points public sector executives (e.g. Chief Information Officers, Chief Digital Officers) involved in the design of governance for the digital toward implementing a conceptual separation of initiatives within the two logics, along with methods, tools and frameworks for management. This includes but is not limited to creating new business case and benefits realization methodologies for the digital innovation logic, as well as dual processes for investment prioritization, i.e. to some extent pursuing structural ambidexterity (Raisch and Birkinshaw, 2008) in a more robust nature where this is associated with changes in governance. It is our belief that this change in governance design will allow for more digital innovation happening within the public sector and the sector as a whole becoming more adept in creating digital services that are deemed relevant for the citizens. Through this, we see that increased capabilities for digital innovation may hold the keys to the increased relevance of public sector actors for society as a whole.

Our study also has two implications for policy. First, the proposed conceptual delineation of the two existing digital logic needs to be mirrored in the policy. Our findings suggest that dual logics require distinct capabilities and the ability of the organization to know, which capabilities to activate when. With the public sector being relatively highly regulated, said regulation needs to provide the basis for this conceptual delineation. Our work within this field has so far resulted in the introduction of the equation of digitalization with the balancing of efficiency and innovation in the SALAR national digital strategy (www.skr.se, 2020). Second, the existing legislation and its interpretation in regard to funding of digital initiatives need to be amended. At present, we see the recommendation and practice of funding digital initiatives through loans as enforcing risk averseness, diminishing digital innovation or pushing it to the shadows of control. The rationale for this is the necessity for balance sheet inclusion of digital initiatives, which invariably decimates the acceptable risk. This answers the call from Hong and Lee (2018) in terms of adaptive policymaking.

Our study has at least one main limitation. The empirical selection of a single case of a large government agency in Sweden is limiting the generalizability of the findings. Despite us not aiming for statistical generalizability but rather theorizing from our observations in a single case, the particularities of Sweden (a politically stable country with a high level of digital maturity) and the size of the agency (large, i.e. destined to be more bureaucratically governed and in need of more economies of scale, i.e. efficiency) decrease the representativeness of the particular results (Bannister, 2007) addressing the efficiency bias. However, we assert that our theorizing involves a good possibility to continue with similar studies on ambidextrous BPs in other organizations.

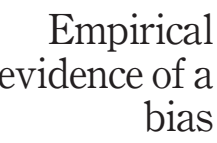


Aronson, J. (1995), “A pragmatic view of thematic analysis", The Qualitative Report, Vol. 2 No. 1, pp. 1-3.

Ask, U., Magnusson, J. and Nilsson, A. (2015), "A Mbidexterity and paradexterity: a typology of IT governance contradictions", AMCIS Conference proceedings, Puerto Rico.

Bannister, F. (2007), "The curse of the benchmark: an assessment of the validity and value of egovernment comparisons", International Review of Administrative Sciences, Vol. 73 No. 2, pp. 171-188.

Benner, M.J. and Tushman, M.L. (2003), "Exploitation, exploration, and process management: the productivity dilemma revisited", Academy of Management Review, Vol. 28 No. 2, pp. 238-256.

Birkinshaw, J. and Gibson, C. (2004), "Building ambidexterity into an organization", MIT Sloan Management Review, Vol. 45, pp. 47-55.

Birkinshaw, J., Zimmermann, A. and Raisch, S. (2016), "How do firms adapt to discontinuous change? Bridging the dynamic capabilities and ambidexterity perspectives", California Management Review, Vol. 58 No. 4, pp. 36-58.

Burgelman, R.A. (2002), "Strategy as vector and the inertia of coevolutionary lock-in", Administrative Science Quarterly, Vol. 47 No. 2, pp. 325-357.

Cannaerts, N., Segers, J. and Warsen, R. (2019), "Ambidexterity and public organizations: a configurational perspective”, Public Performance and Management Review, Vol. 43 No. 3, pp. 1-25.

De Haes, S. and Van Grembergen, W. (2009), "An exploratory study into IT governance implementations and its impact on business/IT alignment", Information Systems Management, Vol. 26 No. 2, pp. 123-137.

Ekbia, H.R. and Nardi, B.A. (2017), Heteromation, and Other Stories of Computing and Capitalism, MIT Press.

Farjoun, M. (2010), "Beyond dualism: stability and change as a duality", Academy of Management Review, Vol. 35 No. 2, pp. 202-225.

Gibson, C.B. and Birkinshaw, J. (2004), "The antecedents, consequences, and mediating role of organizational ambidexterity", Academy of Management Journal, Vol. 47 No. 2, pp. 209-226.

Gieske, H., van Meerkerk, I. and van Buuren, A. (2019), "The impact of innovation and optimization on public sector performance: testing the contribution of connective, ambidextrous, and learning capabilities", Public Performance and Management Review, Vol. 42 No. 2, pp. 432-460.

Gregory, R.W., Kaganer, E., Henfridsson, O. and Ruch, J.T. (2018), "IT consumerization and the transformation of IT governance”, MIS Quarterly, Vol. 42 No. 4, pp. 1225-1253.

Hinings, B., Gegenhuber, T. and Greenwood, R. (2018), "Digital innovation and transformation: an institutional perspective", Information and Organization, Vol. 28 No. 1, pp. 52-61.

Hong, S. and Lee, S. (2018), "Adaptive governance, status quo bias, and political competition: Why the sharing economy is welcome in some cities but not in others", Government Information Quarterly, Vol. 35 No. 2, pp. 283-290.

Janssen, M. and Van Der Voort, H. (2016), “Adaptive governance: towards a stable, accountable and responsive government”, Government Information Quarterly, Vol. 33 No. 1, pp. 1-5.

Janssen, M., Chun, S.A. and Gil-Garcia, J.R. (2009), "Building the next generation of digital government infrastructures", Government Information Quarterly, Vol. 26 No. 2, pp. 233-237.

Kankanhalli, A., Zuiderwijk, A. and Tayi, G.K. (2017), "Open innovation in the public sector: a research agenda", Government Information Quarterly, Vol. 34 No. 1, pp. 84-89.

Kromidha, E. and Córdoba-Pachón, J.R. (2017), "Discursive institutionalism for reconciling change and stability in digital innovation public sector projects for development", Government Information Quarterly, Vol. 34 No. 1, pp. 16-25. 
Lapsley, I. and Wright, E. (2004), "The diffusion of management accounting innovations in the public sector: a research agenda", Management Accounting Research, Vol. 15 No. 3, pp. 355-374.

Leclercq-Vandelannoitte, A. and Emmanuel, B. (2018), "From sovereign IT governance to liberal IT governmentality? A Foucauldian analogy", European Journal of Information Systems, Vol. 27 No. 3, pp. 326-346.

Leonardi, P.M. (2011), "When flexible routines meet flexible technologies: affordance, constraint, and the imbrication of human and material agencies", MIS Quarterly, pp. 147-167.

Levinthal, D.A. (1997), “Adaptation on rugged landscapes”, Management Science, Vol. 43 No. 7, pp. 934-950.

Levinthal, D.A. and March, J.G. (1993), "The myopia of learning”, Strategic Management Journal, Vol. 14 No. S2, pp. 95-112.

Luger, J., Raisch, S. and Swimmer, M. (2018), "Dynamic balancing of exploration and exploitation: the contingent benefits of ambidexterity", Organization Science, Vol. 29 No. 3, pp. 449-470.

Magnusson, J. and Bygstad, B. (2013), "Why I act differently: studying patterns of legitimation among CIOs through motive talk", Information Technology and People, Vol. 26 No. 3, pp. 265-282.

Magnusson, J., Päivärinta, T. and Koutsikouri, D. (2020), "Efficiency creep and shadow innovation: Ambidextrous IT governance in the public sector", Accepted for Publication in European Journal of Information Systems, pp. 1-21.

Magnusson, J., Torell, J., Polutnik, L. and Ask, U. (2017), “Ambidextrous IT governance in the public sector: a revelatory case study of the Swedish tax authorities", In Information Technology Governance in Public Organizations, Springer, Cham, pp. 253-267.

March, J.G. (1991), "Exploration and exploitation in organizational learning", Organization Science, Vol. 2 No. 1, pp. 71-87.

Meijer, A. (2015), "E-governance innovation: barriers and strategies", Government Information Quarterly, Vol. 32 No. 2, pp. 198-206.

Mergel, I., Gong, Y. and Bertot, J. (2018), "Agile government: systematic literature review and future research”, Government Information Quarterly, Vol. 35 No. 2, pp. 291-298.

Montealegre, R., Iyengar, K. and Sweeney, J. (2019), "Understanding ambidexterity: managing contradictory tensions between exploration and exploitation in the evolution of digital infrastructure", Journal of the Association for Information Systems, Vol. 20 No. 5, pp. 647-680.

Nambisan, S., Lyytinen, K., Majchrzak, A. and Song, M. (2017), "Digital innovation management: reinventing innovation management research in a digital world", MIS Quarterly, Vol. 41 No. 1, p. 41.

Nambisan, S., Wright, M. and Feldman, M. (2019), "The digital transformation of innovation and entrepreneurship: progress, challenges and key themes", Research Policy, Vol. 48 No. 8, pp. 103773.

Orlikowski, W.J. and Scott, S.V. (2008), "10 Sociomateriality: challenging the separation of technology, work and organization”, Academy of Management Annals, Vol. 2 No. 1, pp. 433-474.

O'Reilly III, C.A. and Tushman, M.L. (2008), "Ambidexterity as a dynamic capability: resolving the innovator's dilemma”, Research in Organizational Behavior, Vol. 28, pp. 185-206.

Palm, K. and Lilja, J. (2017), "Key enabling factors for organizational ambidexterity in the public sector”, International Journal of Quality and Service Sciences, Vol. 9 No. 1, pp. 2-29.

Peng, H. (2019), "Organizational ambidexterity in public non-profit organizations: interest and limits", Management Decision, Vol. 57 No. 1, pp. 248-261.

Piccinini, E., Hanelt, A., Gregory, R. and Kolbe, L. (2015), "Transforming industrial business: the impact of digital transformation on automotive organizations", in Proceedings of the 36th International Conference on Information Systems, Fort Worth.

Raisch, S. and Birkinshaw, J. (2008), "Organizational ambidexterity: antecedents, outcomes, and moderators”, Journal of Management, Vol. 34 No. 3, pp. 375-409. 
Ranerup, A. and Henriksen, H.Z. (2019), "Value positions viewed through the lens of automated decision-making: the case of social services", Government Information Quarterly, Vol. 36 No. 4, p. 101377.

Rolland, K.H., Mathiassen, L. and Rai, A. (2018), "Managing digital platforms in user organizations: the interactions between digital options and digital debt", Information Systems Research, Vol. 29 No. 2, pp. 419-443.

Sandberg, J., Mathiassen, L. and Napier, N. (2014), "Digital options theory for IT capability investment", Journal of the Association for Information Systems, Vol. 15 No. 7, p. 1.

Scupola, A. and Zanfei, A. (2016), "Governance and innovation in public sector services: the case of the digital library”, Government Information Quarterly, Vol. 33 No. 2, pp. 237-249.

Selander, L. and Jarvenpaa, S.L. (2016), "Digital action repertoires and transforming a social movement organization”, MIS Quarterly, Vol. 40 No. 2, pp. 331-352.

Smith, E. and Umans, T. (2015), "Organizational ambidexterity at the local government level: the effects of managerial focus", Public Management Review, Vol. 17 No. 6, pp. 812-833.

Smith, W.K., Lewis, M.W. and Tushman, M.L. (2016), "Both/and leadership”, Harvard Business Review, Vol. 94 No. 5 , pp. $62-70$.

Soe, R.M. and Drechsler, W. (2018), “Agile local governments: experimentation before implementation”, Government Information Quarterly, Vol. 35 No. 2, pp. 323-335.

Stieglitz, N., Knudsen, T. and Becker, M.C. (2016), "Adaptation and inertia in dynamic environments", Strategic Management Journal, Vol. 37 No. 9, pp. 1854-1864.

Svahn, F. and Henfridsson, O. (2012), "The dual regimes of digital innovation management", HICSS Conference proceedings.

Svahn, F., Mathiassen, L. and Lindgren, R. (2017), "Embracing digital innovation in incumbent firms: how Volvo cars managed competing concerns", MIS Quarterly, Vol. 41 No. 1, pp. 41.

Walsham, G. (1995), "Interpretive case studies in is research, nature and method", European Journal of Information Systems, Vol. 4 No. 2, pp. 74-81.

Wang, C., Medaglia, R. and Zheng, L. (2018), "Towards a typology of adaptive governance in the digital government context: the role of decision-making and accountability", Government Information Quarterly, Vol. 35 No. 2, pp. 306-322.

www.skr.se (2020), available at: https://skr.se/naringslivarbetedigitalisering/digitalisering/ strategifordigitalutveckling.6728.html, (accessed 10 February 2020).

Xue, L., Ray, G. and Sambamurthy, V. (2012), "Efficiency or innovation: how do industry environments moderate the effects of firms' IT asset portfolios? ”, MIS Quarterly, Vol. 36 No. 2, pp. 509-528.

Yin, R.K. (1989), Case Study Research - Design and Methods, 2nd ed., Sage, Newbury Park, CA.

Yoo, Y., Henfridsson, O. and Lyytinen, K. (2010), "Research commentary—the new organizing logic of digital innovation: an agenda for information systems research", Information Systems Research, Vol. 21 No. 4, pp. 724-735.

Zittrain, J. (2006), The Generative Internet, 119 Harvard Law Review 1974, 1980-1982.

Zimmermann, A., Raisch, S. and Cardinal, L.B. (2018), "Managing persistent tensions on the frontline: a configurational perspective on ambidexterity", Journal of Management Studies, Vol. 55 No. 5, pp. $739-769$.

\section{Appendix. Interview guide}

- Can you describe your role and main responsibilities in the organization?

- How long have you been working for the SIA? 


\section{Pre-conditions for innovation}

- What does "innovation" mean to you?

- How does SIA work with the development of new services?

- How would you describe the internal innovation capability within your work area?

- How would you perceive the innovation capability within the SIA?

- How would you describe the main drivers for innovating within the SIA?

- What are the incentives for initiating innovation (activities) in the SIA?

- What type of processes, if any, are in place to capture ideas?

- What are the barriers to initiating innovation (activities)?

- In your opinion, what characterizes a truly innovative organization? (e.g. attributes and dimensions)

\section{Governance}

- How would you describe the need for governance vs the need for innovation capability?

- How do you motivate the basis for your investment decisions?

- Tell us about how you prioritize your investment decisions.

- In your opinion, how could the innovation process in the SIA be improved?

\section{Digitalization and change}

- How do you perceive SIA's ability to make the most of the opportunities offered by digitalization?

- In your opinion, what are the main barriers to support digitalization with the SIA?

- How would you describe the culture in your work area within the SIA?

\section{General}

- What other aspects would you like to add and which relates to governance and/or innovation within the SIA?

\section{Corresponding author}

Johan Magnusson can be contacted at: johan.magnusson@gu.se

For instructions on how to order reprints of this article, please visit our website: 